\title{
Ignition Delay Characteristics of Kerosene with Decomposed Hydrogen Peroxide
}

\author{
Sen Li* and Xiaolin Wei \\ Chinese Academy of Sciences, 100190 Beijing, People's Republic of China
}

DOI: $10.2514 / 1 . B 35723$

\begin{abstract}
The ignition chemical delay of kerosene with decomposed hydrogen peroxide was simulated by using $\boldsymbol{n}$-decane as a surrogate fuel for kerosene. The influences of $\mathrm{H}_{2} \mathrm{O}_{2}$ concentration, the $\mathrm{H}_{2} \mathrm{O}_{2}$ decomposition rate, and pressure on the chemical delay were investigated. The ignition delay time had the negative temperature coefficient phenomenon for a low $\mathrm{H}_{2} \mathrm{O}_{2}$ decomposition rate, and the increasing pressure weakened the negative temperature coefficient phenomenon, which nearly disappeared when the pressure was greater than $4 \mathrm{MPa}$. An $R_{\mathrm{H} 2 \mathrm{O} 2}$-dependent coefficient of the ignition delay time was almost not influenced by $\mathrm{H}_{2} \mathrm{O}_{2}$ concentration and pressure when the pressure was less than $4 \mathrm{MPa}$, and $R_{\mathrm{H} 2 \mathrm{O} 2}$ had a noticeable influence on the ignition delay time at $R_{\mathrm{H} 2 \mathrm{O} 2}<80 \%$. Increasing the $\mathrm{H}_{2} \mathrm{O}_{2}$ concentration effectively reduced the ignition delay time at $R_{\mathrm{H} 202}<70 \%$, but it had a slight effect on the ignition delay time at $\boldsymbol{R}_{\mathrm{H} 2 \mathrm{O} 2}>\mathbf{7 0} \%$.
\end{abstract}

\section{Nomenclature}

$C_{\mathrm{H} 2 \mathrm{O} 2}=\mathrm{H}_{2} \mathrm{O}_{2}$ concentration, $\%$

$P=$ pressure, $\mathrm{MPa}$

$R_{\mathrm{H} 2 \mathrm{O} 2}=\mathrm{H}_{2} \mathrm{O}_{2}$ decomposition rate, $\%$

$\zeta=R_{\mathrm{H} 2 \mathrm{O} 2}$-dependent coefficient of ignition delay time

$\tau_{i g} \quad=$ ignition delay time, $\mu \mathrm{s}$

$\tau_{\max }=$ maximal ignition delay time, $\mu \mathrm{s}$

$\tau_{\min }=$ minimal ignition delay time, $\mu \mathrm{s}$

$\tau_{1} \quad=$ first-stage ignition delay time

$\tau_{2} \quad=$ second-stage ignition delay time

$\varphi=$ equivalence ratio

\section{Introduction}

$\mathbf{I}^{\mathrm{N}}$ N RECENT years, to enhance safety and reduce the toxicity of liquid rocket engines, the green propellants have received wide attention, and the combination of kerosene with $\mathrm{H}_{2} \mathrm{O}_{2}$ is promising due to its high-density specific impulse, long-term storage capability, and low toxicity $[1,2]$. Many studies are focusing on developing $\mathrm{H}_{2} \mathrm{O}_{2}$ / kerosene bipropellant liquid engines [3].

Rocket-grade hydrogen peroxide (RGHP) is characterized by a high mass ratio of hydrogen peroxide to water (usually greater than $85 \%$ ) [4]. In a rocket engine, RGHP is passed through a catalyst bed (silver screens or other catalytic material) and aft-mounted injector, and the catalyst bed initiates RGHP decomposition [5-7]. Assuming that $90 \% \mathrm{H}_{2} \mathrm{O}_{2}$ is decomposed, the decomposition reaction for this concentration can be written as

$$
\mathrm{H}_{2} \mathrm{O}_{2}(\mathrm{l})+0.21 \mathrm{H}_{2} \mathrm{O}(\mathrm{l}) \Rightarrow 1.21 \mathrm{H}_{2} \mathrm{O}(\mathrm{g})+0.5 \mathrm{O}_{2}(\mathrm{~g})
$$

The RGHP decomposition mixture of high-temperature steam and oxygen leads to the automatic ignition of kerosene in a rocket engine, and the ignition delay is a critical kinetic parameter [3,7]. If the ignition does not occur on time, propellants can accumulate in the chamber and then spontaneously ignite, resulting in the chamber bursting and combustion instability, which leads to rocket engine failure [8]. The ignition delay of hypergolic propellants depends on

Received 8 January 2015; revision received 24 September 2015; accepted for publication 27 September 2015; published online 21 December 2015. Copyright $\odot 2015$ by the American Institute of Aeronautics and Astronautics, Inc. All rights reserved. Copies of this paper may be made for personal or internal use, on condition that the copier pay the $\$ 10.00$ per-copy fee to the Copyright Clearance Center, Inc., 222 Rosewood Drive, Danvers, MA 01923; include the code 1533-3876/15 and \$10.00 in correspondence with the CCC.

*State Key Laboratory of High Temperature Gas Dynamics, Institute of Mechanics, 15 Beisihuanxi Road.

'State Key Laboratory of High Temperature Gas Dynamics, Institute of Mechanics, 15 Beisihuanxi Road. the complex interactions between many chemical and physical factors, the process of ignition delay includes the physical delay (atomization, mixing, vaporization, and diffusion) and the chemical delay (gas phase reactions), and the characteristic times of each process combine to form a global ignition delay time [9-12]. The physical delay is greatly influenced by the injection technique, which varies with the injector configuration and injecting parameters, and the chemical delay is determined by the reaction potential of the two propellants (such as fuel structure, mixture composition, the fuel/air ratio, temperature, and pressure) [13].

There is relatively little information about the ignition delay characteristics of kerosene with the decomposed hydrogen peroxide. In this study, the ignition physical delay is not considered; the ignition chemical delay of kerosene with decomposed hydrogen peroxide is simulated by using $n$-decane as a surrogate fuel for kerosene; and the influences of $C_{\mathrm{H} 2 \mathrm{O} 2}, R_{\mathrm{H} 2 \mathrm{O} 2}$, and pressure on the chemical delay are investigated in a perfectly stirred reactor model.

\section{Methodology}

\section{A. Reaction Mechanism for $\boldsymbol{n}$-Decane}

The commercial Jet-A1 is kerosene-type fuel, it is complex mixtures of a large number of different hydrocarbons, and the developing chemical kinetic models of kerosene combustion is of practical importance. Because of the very large chemical kinetic mechanisms and the associated computational resources required, the simulation of kerosene combustion is challenging [14]. Zeng et al. [15] and Dagaut and Cathonnet [16] used a surrogate fuel containing only $n$-decane to simulate kerosene combustion at 1-4 MPa. Chang et al. [17] developed a new skeletal mechanism including 40 species and $1 \overline{41}$ reactions for $n$-decane oxidation to simulate kerosene combustion, the mechanism for $\mathrm{C}_{2}-\mathrm{C}_{10}$ was used to model the oxidation of heavy hydrocarbons for the prediction of the ignition characteristics, and it was extensively validated by comparing it to the experimental ignition delay data of $n$-decane oxidation under the low-to-high temperature and high-pressure conditions [18]. In the study, the skeletal mechanism developed by Chang et al. is used to simulate the ignition delay characteristics of kerosene with the decomposed hydrogen peroxide.

\section{B. Homogeneous Reactor}

To understand the ignition delay mechanism of kerosene with $\mathrm{H}_{2} \mathrm{O}_{2}$ decomposition gas in a rocket engine, the homogeneous, isobaric, and adiabatic combustion reactor model is employed to predict the ignition time, and it can qualitatively discover the effects of operating parameters on the ignition delay process.

The chemical kinetic behavior of reactants is modeled by Sandia National Laboratory's SENKIN program of CHEMKIN subroutines 
$[18,20]$. The program solves the conservation equations for mass and energy, it can calculate the temporal evolution of mole fractions of species for a homogeneous mixture in a closed reactor, and it can account for finite-rate elementary chemical reactions. Therefore, the SENKIN model is appropriate to investigate the ignition chemical delay of kerosene with $\mathrm{H}_{2} \mathrm{O}_{2}$ decomposition gas in a closed chamber. In this reactor model, the reactive system is defined by specifying initial values of volume, temperature, pressure, and chemical compositions. Based on a steepest-increase criterion of the temperature, $\tau_{i g}$ is extracted. The reaction pathway flux analysis is performed using MixMaster (a Python program that is part of the Cantera suite) based on a conserved scalar of reaction fluxes [18].

\section{Simulation Conditions}

Using a thermodynamic equilibrium model based on the minimization of Gibbs free energy, the dominant products of $\mathrm{H}_{2} \mathrm{O}_{2}$ decomposition are $\mathrm{H}_{2} \mathrm{O}$ and $\mathrm{O}_{2}$, the mass concentration sum of other productions is less than $10^{-5}$ in the operating conditions of catalyst beds using silver screens, and thus it is considered that the decomposition products are only $\mathrm{H}_{2} \mathrm{O}$ and $\mathrm{O}_{2}$. The effect of pressure on the $\mathrm{H}_{2} \mathrm{O}_{2}$ decomposition temperature was reported by General Kinetics [21]. According to the real gas specific heat and standard formation enthalpy of $\mathrm{H}_{2} \mathrm{O}_{2}, \mathrm{O}_{2}$, and $\mathrm{H}_{2} \mathrm{O}$, the decomposition temperature is calculated [21,22], and Ge et al. [22] provided the calculation method and formula. Figure 1 shows the decomposition temperature of $87-$ $92 \% \mathrm{H}_{2} \mathrm{O}_{2}$ at $1 \mathrm{MPa}$.

For a given $\mathrm{C}_{\mathrm{H} 2 \mathrm{O} 2}$, when $\mathrm{H}_{2} \mathrm{O}_{2}$ is completely decomposed in the catalyst bed, the mass fractions of $\mathrm{O}_{2}$ and $\mathrm{H}_{2} \mathrm{O}$ in the highdecomposition gas mixture are

$$
\begin{gathered}
f_{\mathrm{O} 2}=0.47037 C_{\mathrm{H} 2 \mathrm{O} 2} / 100 \\
f_{\mathrm{H} 2 \mathrm{O}}=1-0.47037 C_{\mathrm{H} 2 \mathrm{O} 2} / 100
\end{gathered}
$$

To avoid catalyst bed overtemperature or the instability in the practical operation of the rocket engine, $\mathrm{H}_{2} \mathrm{O}_{2}$ is partly decomposed in the catalyst bed, and the residual $\mathrm{H}_{2} \mathrm{O}_{2}$ in the supercritical liquid state is injected into combustion chamber, which has no sufficient time to participate in the ignition due to the delay of the vaporization and decomposition process. Thus, it is necessary to investigate the effect of $R_{\mathrm{H} 2 \mathrm{O} 2}$ on the ignition delay of kerosene with the $\mathrm{H}_{2} \mathrm{O}_{2}$ decomposition gas. At given $C_{\mathrm{H} 2 \mathrm{O} 2}$ and $R_{\mathrm{H} 2 \mathrm{O} 2}$, the mass fractions of $\mathrm{O}_{2}, \mathrm{H}_{2} \mathrm{O}$, and the residual $\mathrm{H}_{2} \mathrm{O}_{2}$ in the high-decomposition mixture are

$$
f_{\mathrm{O} 2}=0.47037 \times\left(C_{\mathrm{H} 2 \mathrm{O} 2} / 100\right) \times\left(R_{\mathrm{H} 2 \mathrm{O} 2} / 100\right)
$$

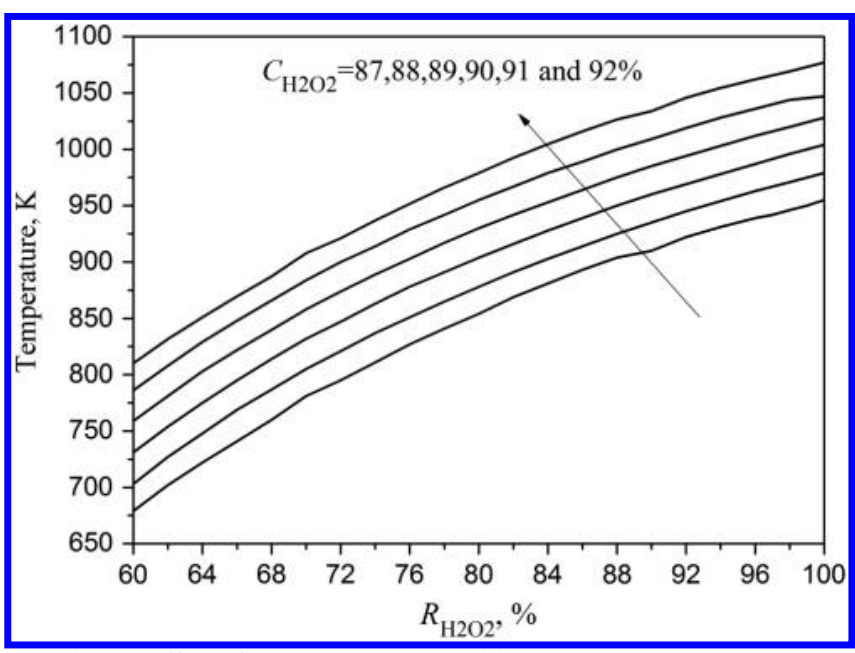

Fig. 1 Effect of $R_{\mathrm{H} 2 \mathrm{O} 2}$ on decomposition temperature at $1 \mathrm{MPa}$.

$$
\begin{gathered}
f_{\mathrm{H} 2 \mathrm{O}}=\left(1-0.52963 \times R_{\mathrm{H} 2 \mathrm{O} 2} / 100\right) \times C_{\mathrm{H} 2 \mathrm{O} 2} / 100 \\
f_{\mathrm{H} 2 \mathrm{O} 2}=\left(1-R_{\mathrm{H} 2 \mathrm{O} 2} / 100\right) \times C_{\mathrm{H} 2 \mathrm{O} 2} / 100
\end{gathered}
$$

In the ignition simulation of kerosene with decomposed hydrogen peroxide at a given $C_{\mathrm{H} 2 \mathrm{O} 2}, R_{\mathrm{H} 2 \mathrm{O} 2}$ influences the initial ignition temperature and $\varphi$, and $\varphi$ is defined as

$$
\varphi=\frac{\left(m_{\mathrm{C} 10 \mathrm{H} 22} / m_{\mathrm{H} 2 \mathrm{O} 2}\right)_{\text {actual mixture }}}{\left(m_{\mathrm{C} 10 \mathrm{H} 22} / m_{\mathrm{H} 2 \mathrm{O} 2}\right)_{\text {stoichiometric mixture }}}
$$

where $m_{\mathrm{C} 10 \mathrm{H} 22}$ and $m_{\mathrm{H} 2 \mathrm{O} 2}$ are the mass contents of $\mathrm{C}_{10} \mathrm{H}_{22}$ and $\mathrm{H}_{2} \mathrm{O}_{2}$, respectively. In the study, $m_{\mathrm{C} 10 \mathrm{H} 22}$ is kept at a constant, $\varphi$ is kept at a constant of 1.0 when $\mathrm{H}_{2} \mathrm{O}_{2}$ is completely decomposed $\left(R_{\mathrm{H} 2 \mathrm{O} 2}=100 \%\right)$, the actual amount of $m_{\mathrm{H} 2 \mathrm{O} 2}$ participating in the ignition reactions is equal to the product of stoichiometric $\mathrm{H}_{2} \mathrm{O}_{2}$ mass and $R_{\mathrm{H} 2 \mathrm{O} 2} / 100$, and then $\varphi$ is derived from Eq. (7):

$$
\varphi=100 / R_{\mathrm{H} 2 \mathrm{O} 2}
$$

As known from Eq. (8), decreasing $R_{\mathrm{H} 2 \mathrm{O} 2}$ means that the equivalence ratio decreases, and the ignition is under a fuel-rich atmosphere at $\varphi<1.0$. In the study, the $\mathrm{H}_{2} \mathrm{O}_{2}$ concentration and decomposition rate vary from 87 to $92 \%$ and 60 to $100 \%$, respectively.

\section{Results and Discussion}

\section{A. Ignition Process Analysis}

In the study, a high-temperature gas stream of the decomposed hydrogen peroxide mixes with $n$-decane, and the autoignition can be achieved. Ignition is an oxidizing fuel and increasing temperature process. Figure 2 shows the temperature history of the mixture as it undergoes ignition for various $R_{\mathrm{H} 2 \mathrm{O} 2}$ at $1 \mathrm{MPa}$ and $C_{\mathrm{H} 2 \mathrm{O} 2}=87 \%$, and it indicates that the entire period of the ignition delay is a twostage temperature increment process (namely, two-stage ignition, 0A and A-B) for low $R_{\mathrm{H} 2 \mathrm{O} 2}(64,74$, and $84 \%)$ or a single-stage temperature increment process (namely, single-stage ignition) for high $R_{\mathrm{H} 2 \mathrm{O} 2}$ (94 and $100 \%$ ).

The behavior of two-stage ignition for low $R_{\mathrm{H} 2 \mathrm{O} 2}$ in Fig. 2 is further demonstrated in Fig. 3 . With the increase of $R_{\mathrm{H} 2 \mathrm{O} 2}, \tau_{1}$ monotonically decreases, and $\tau_{1}$ is nearly equal to $0 \mu \mathrm{s}$ at $R_{\mathrm{H} 2 \mathrm{O} 2}>88 \% ; \tau_{2}$ first increases at $R_{\mathrm{H} 2 \mathrm{O} 2}<88 \%$ and then decreases; it indicates that the ignition delay is two stages at $R_{\mathrm{H} 2 \mathrm{O} 2}<88 \%$ and a single stage at $R_{\mathrm{H} 2 \mathrm{O} 2}>88 \%$; the total ignition delay time $\tau_{i g}$ is the sum of $\tau_{1}$ and $\tau_{2}$, and the ignition delay mainly results from the first-stage delay at $R_{\mathrm{H} 2 \mathrm{O} 2}<68 \%$.

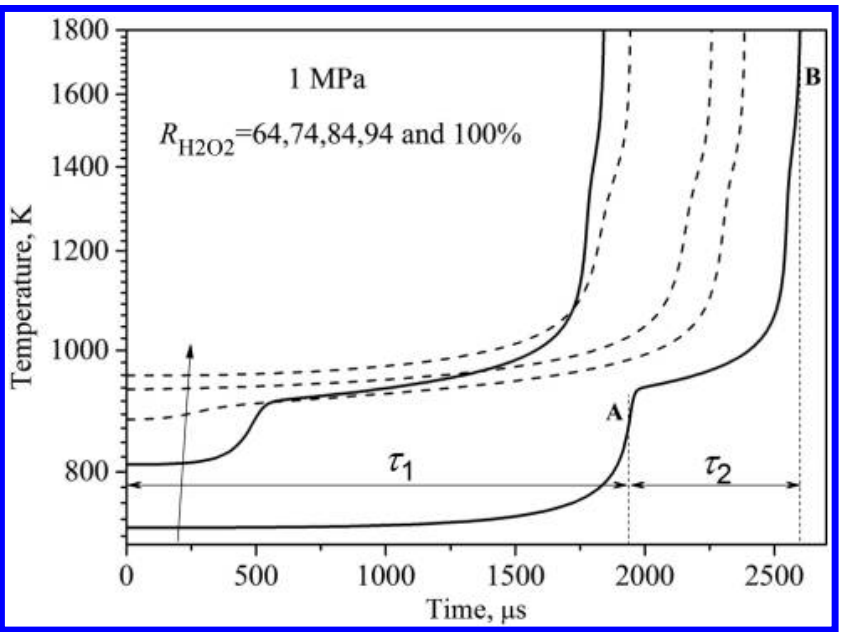

Fig. 2 Temperature variations in the ignition process at $1 \mathrm{MPa}$ and $87 \%$ $C_{\mathrm{H} 2 \mathrm{O} 2}$. 


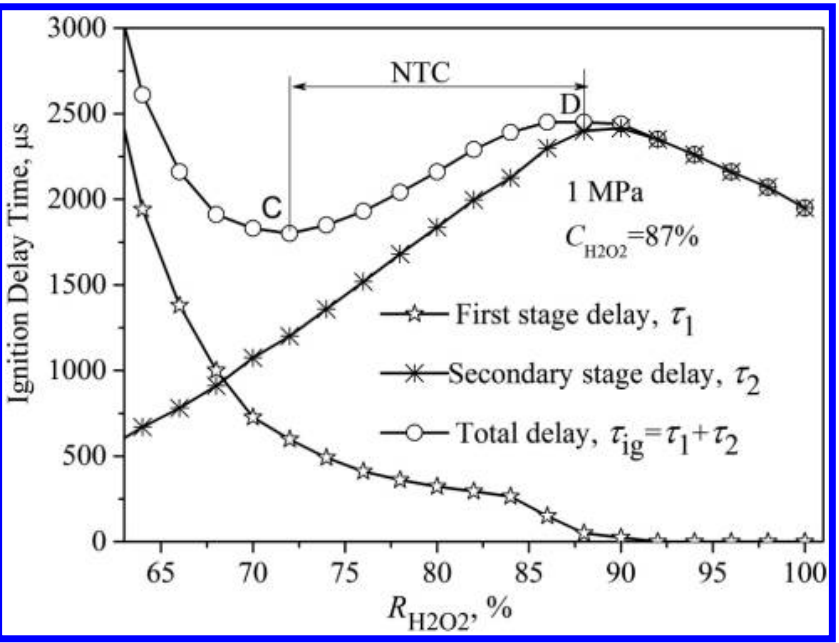

Fig. 3 Two-stage ignition process at $1 \mathrm{MPa}$.

Figure 3 , with the increase of $R_{\mathrm{H} 2 \mathrm{O} 2}, \tau_{i g}$ first decreases at $R_{\mathrm{H} 2 \mathrm{O} 2}<$ $72 \%$ and then increases at $R_{\mathrm{H} 2 \mathrm{O} 2}=72-88 \%$. As is known from Fig. 1, the temperature of the $\mathrm{H}_{2} \mathrm{O}_{2}$ decomposition gas increases with the increase of $R_{\mathrm{H} 2 \mathrm{O} 2}$, and thus there is a negative temperature coefficient (NTC) phenomenon in the C-D region where $\tau_{i g}$ increases with the increase of the initial ignition temperature. Practically, the NTC phenomenon is of particular relevance to the intrinsically lowtemperature phenomenon of ignition for the low-temperature oxidation of large hydrocarbons [를.

As is known from Figs. 2 and 3 , the ignition process goes through two stages to achieve intense burning at $R_{\mathrm{H} 2 \mathrm{O} 2}<88 \%$, but it goes through only one stage, controlled by low-temperature chemistry, at $R_{\mathrm{H} 2 \mathrm{O} 2}>88 \%$. To understand the dominant chemical reaction mechanism of ignition at the points of $\mathrm{A}$ and $\mathrm{B}$ in Figs. 2 and $\underline{4}$ provides the species concentration variations with time in the ignition process for $C_{\mathrm{H} 2 \mathrm{O} 2}=87 \%$ and $R_{\mathrm{H} 2 \mathrm{O} 2}=64 \%$ at $1 \mathrm{MPa}$. In Figs. $4 \mathrm{a}$ and $\underline{4 b}$, with the increase of time, these species except $\mathrm{C}_{10} \overline{\mathrm{H}_{22}}$ gradually increase, there is a single peak of point A (at $1941 \mu \mathrm{s}$ ) where hydrocarbon species sharply decrease (see Figs. $4 \mathrm{a}$ and $4 \mathrm{~b}$ ) and the temperature rapidly increases to $822 \mathrm{~K}$ at point A (see Fig. $\overline{2}$ ), and thus the first-stage ignition occurs at point $\mathrm{A}$. In the first-stage ignition, $\mathrm{C}_{10} \mathrm{H}_{22}$ is decomposed and oxidized with the slow increase of the temperature, the temperature increases from 722 to $822 \mathrm{~K}$, and thus the first-stage ignition is governed by the low-temperature chemistry. At point B in Fig. 2 (at $2606 \mu \mathrm{s}$ ), the concentrations of hydrocarbon species dramatically decrease in Figs. $4 \mathrm{c}$ and $4 \mathrm{~d}$, the temperature sharply increases to $1828 \mathrm{~K}$, and thus the secondarystage ignition occurs at point B in Fig. 2 , which is governed by the high-temperature chemistry.

To analyze the reaction mechanisms of the low-temperature chemistry and the high-temperature chemistry in the ignition process, the reaction paths are investigated at 1930 and $2548 \mu \mathrm{s}$, as shown in Fig. 5.

Figure 5 shows the low-temperature reaction path of the first-stage ignition at $1941 \mu \mathrm{s}$, and the low-temperature chain sequence is as follows. First, $\mathrm{H}$ is abstracted from $\mathrm{C}_{10} \mathrm{H}_{22}$ by $\mathrm{OH}$ and $\mathrm{H}$ radicals to form the heptyl radicals $\left(\mathrm{C}_{10} \mathrm{H}_{21}\right)$ :

$$
\begin{gathered}
\mathrm{C}_{10} \mathrm{H}_{22}+\mathrm{H} \rightarrow \mathrm{C}_{10} \mathrm{H}_{21}+\mathrm{H}_{2} \\
\mathrm{C}_{10} \mathrm{H}_{22}+\mathrm{OH} \rightarrow \mathrm{C}_{10} \mathrm{H}_{21}+\mathrm{H}_{2} \mathrm{O}
\end{gathered}
$$

$\mathrm{H}$ and $\mathrm{OH}$ radicals attack $\mathrm{C}_{10} \mathrm{H}_{22}$ to result in $\mathrm{H}$ abstraction, and the major consuming fuel paths are exothermic reactions.

Second, the heptyl radical $\left(\mathrm{C}_{10} \mathrm{H}_{21}\right)$ combines with $\mathrm{O}_{2}$ to form the heptylperoxy radical $\left(\mathrm{C}_{10} \mathrm{H}_{21} \mathrm{OO}\right)$ :

$$
\mathrm{C}_{10} \mathrm{H}_{21}+\mathrm{O}_{2} \rightarrow \mathrm{C}_{10} \mathrm{H}_{21} \mathrm{OO}
$$

11 is one of the major heat release reactions in the low-temperature reaction of the first-stage ignition; 11 can process toward the inverse direction with the increase of temperature, and then it has an inverse temperature dependence.

Third, the isomerization of heptylperoxy $\left(\mathrm{C}_{10} \mathrm{H}_{21} \mathrm{OO}\right)$ forms the heptylhydroperoxy radicals $\left(\mathrm{C}_{10} \mathrm{H}_{20} \mathrm{OOH}\right)$ :

$$
\mathrm{C}_{10} \mathrm{H}_{21} \mathrm{OO} \rightarrow \mathrm{C}_{10} \mathrm{H}_{20} \mathrm{OOH}
$$

12 is an endothermic reaction.

Fourth, the $\mathrm{C}_{10} \mathrm{H}_{20} \mathrm{OOH}$ proceeds to take the chain branching reaction with the second $\mathrm{O}_{2}$ addition to form $\mathrm{OOC}_{10} \mathrm{H}_{20} \mathrm{OOH}$ :

$$
\mathrm{C}_{10} \mathrm{H}_{20} \mathrm{OOH}+\mathrm{O}_{2} \rightarrow \mathrm{OOC}_{10} \mathrm{H}_{20} \mathrm{OOH}
$$

$\mathrm{OOC}_{10} \mathrm{H}_{20} \mathrm{OOH}$ then forms ketohydroperoxide $\left(\mathrm{C}_{10}\right.$ ket $)$ by releasing $\mathrm{OH}$ :

$$
\mathrm{OOC}_{10} \mathrm{H}_{20} \mathrm{OOH} \rightarrow \mathrm{C}_{10} \mathrm{ket}+\mathrm{OH}
$$

Moreover, the ketohydroperoxide molecule undergoes decomposition to form $\mathrm{C}_{5} \mathrm{H}_{11} \mathrm{CO}$, olefin, and formaldehyde in reaction:

$$
\mathrm{C}_{10} \text { ket } \rightarrow \mathrm{CH}_{2} \mathrm{O}+\mathrm{C}_{5} \mathrm{H}_{11} \mathrm{CO}+\mathrm{OH}+\mathrm{C}_{3} \mathrm{H}_{6}
$$

The ketones $\left(\mathrm{C}_{10} \mathrm{ket}\right)$ decomposition reaction of 15 is the most important low-temperature endothermic chain branching reaction. The $\mathrm{C}_{5} \mathrm{H}_{11} \mathrm{CO}$ continues to decompose into $\mathrm{C}_{0}-\mathrm{C}_{3}$ species:

$$
\mathrm{C}_{5} \mathrm{H}_{11} \mathrm{CO}+\mathrm{O}_{2} \rightarrow \mathrm{C}_{3} \mathrm{H}_{7}+\mathrm{C}_{2} \mathrm{H}_{3}+\mathrm{CO}+\mathrm{HO}_{2}
$$

Finally, the carbonyl decomposition reactions generate smaller $\mathrm{C}_{1}$ and $\mathrm{C}_{2}$ radicals, which subsequently undergo further reactions:

$$
\mathrm{C}_{2} \mathrm{H}_{3}+\mathrm{O}_{2} \rightarrow \mathrm{CH}_{2} \mathrm{O}+\mathrm{HCO}
$$

Specifically, it is noted that the isomerization and decomposition reactions have the dominant effect on the first ignition stage.

In the previous reactions, $\underline{10}, \underline{11}, \underline{13}, \underline{14}$, and $\underline{17}$ are important exothermic reactions, the concentration of $\mathrm{OH}$ radical originating from 14 and 15 increases with the increase of time at 1800-2020 $\mu$ s, and this accelerates the reaction rate of 17 and the rise of temperature until the temperature rises to a value at which the 16 reaction becomes the important reaction:

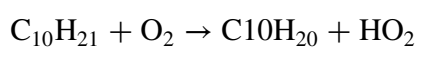

$\mathrm{H}_{2} \mathrm{O}_{2}$ is formed:

$$
\mathrm{HO}_{2}+\mathrm{HO}_{2} \rightarrow \mathrm{H}_{2} \mathrm{O}_{2}+\mathrm{O}_{2}
$$

In the first-stage ignition process, the $\mathrm{OH}$ radical is largely consumed in the range of 1940 to $1960 \mu \mathrm{s}$, the temperature noticeably rises (see Fig. 2), 11 shifts toward the decomposition of the $\mathrm{C}_{10} \mathrm{H}_{21} \mathrm{OO}$ radical, the production rate of $\mathrm{OH}$ decreases, and then the low-temperature chemistry of the first-stage ignition is shut down [23].

Since the reaction rates of 18 and 19 increase with the increase of temperature in the first-stage ignition, 18 competes with the reactions of $\underline{11}, 13,14$, and 17 ; this suppresses $\mathrm{O} \overline{\mathrm{H}}$ radical formation and results in the decrease of the 10 reaction rate, and then 18 reaction becomes important, terminating the first-stage ignition when the temperature rises to $822 \mathrm{~K}$ (see point A in Figs. 2, 4a , and $\underline{4 b}$ ).

In the second-ignition stage, initially, 18 becomes a dominant path reaction involving slightly exothermic process, it suppresses the formation of the $\mathrm{OH}$ radical, $\mathrm{OH}$ concentration begins to decrease after the first-stage ignition, the 10 reaction rate decreases, this results in the decrease of the $\mathrm{C}_{10} \mathrm{H}_{21}$ concentration (see Figs. $\underline{4 a}$ and $\underline{4 b}$ ), and the temperature slowly rises (see Fig. 2 ) until 20 becomes an important reaction: 


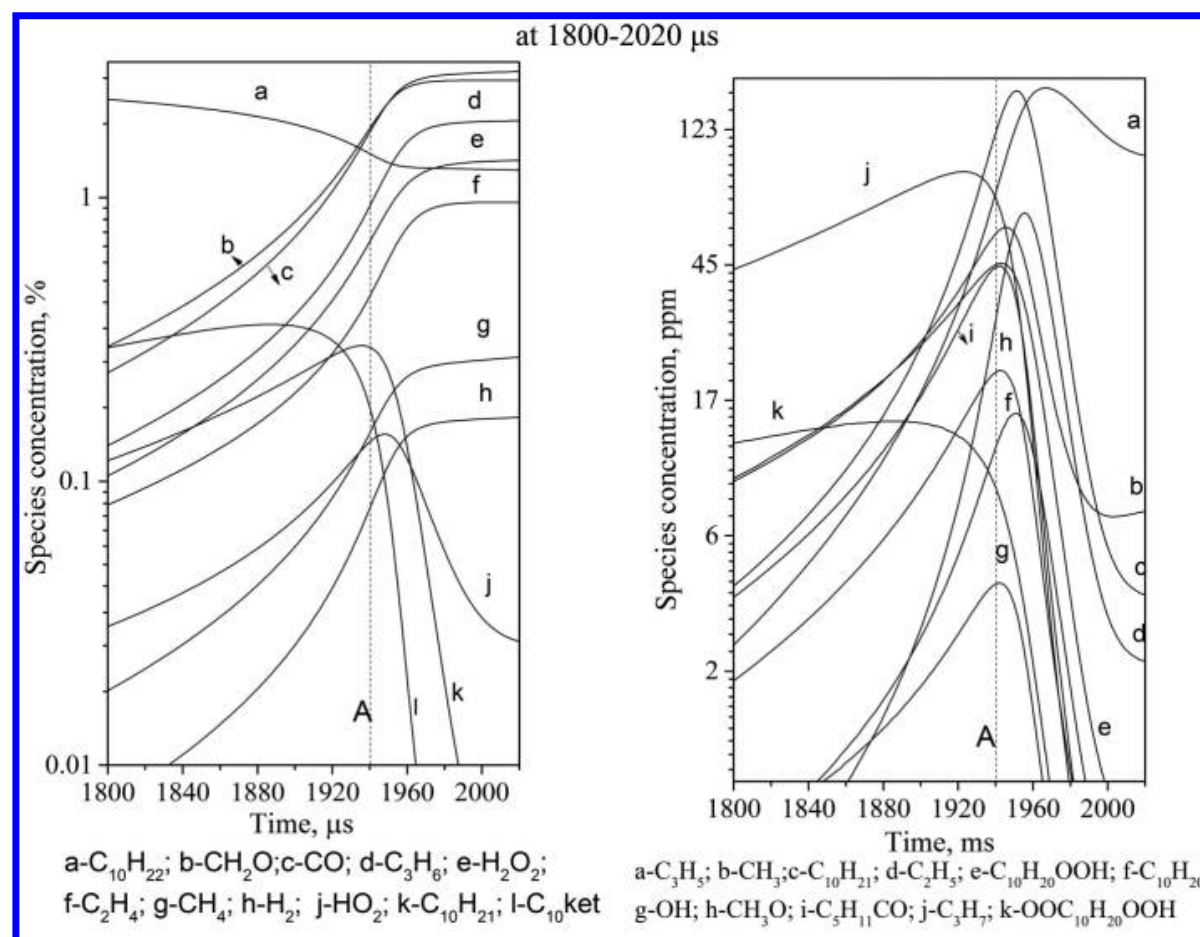

at $2020-2650 \mu \mathrm{s}$
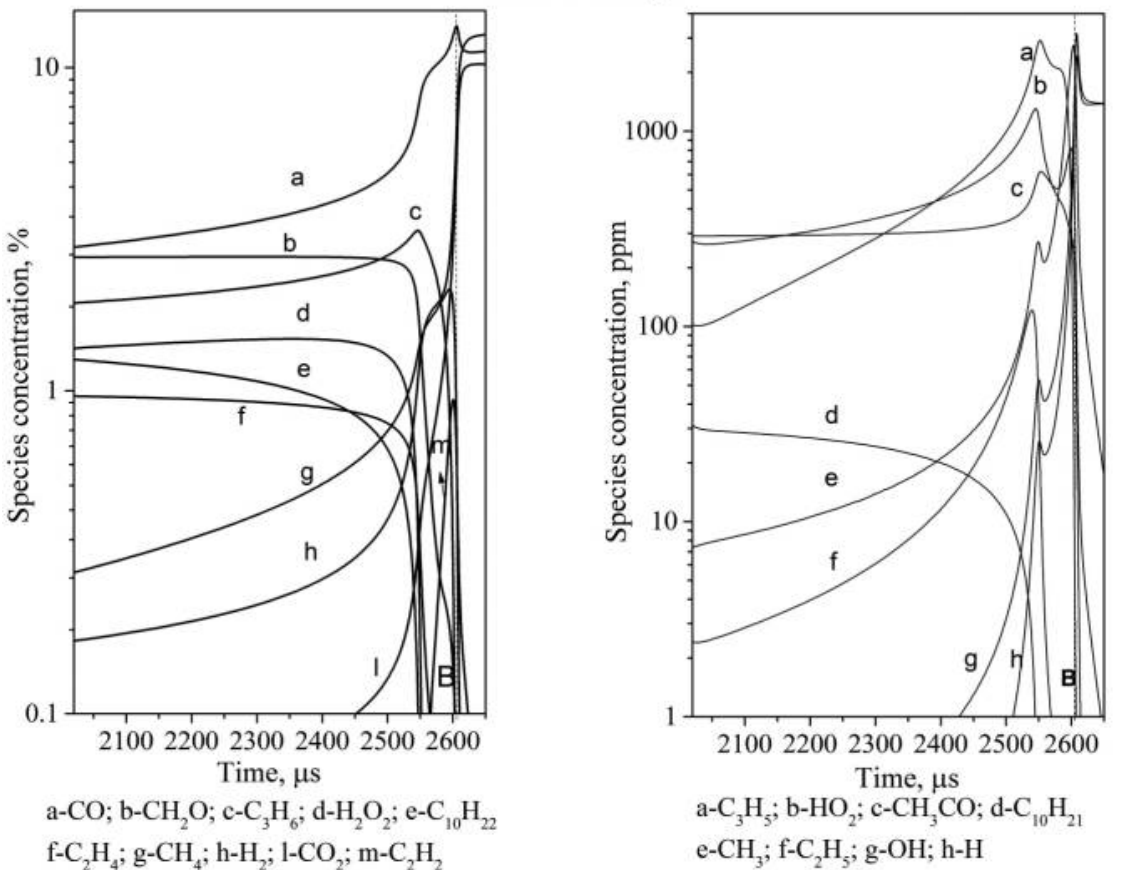

Fig. 4 Concentration variations of species in the ignition process at $87 \% C_{\mathrm{H} 2 \mathrm{O} 2}, 64 \% R_{\mathrm{H} 202}$, and $1 \mathrm{MPa}$.

$$
\mathrm{H}_{2} \mathrm{O}_{2}(+\mathrm{M}) \rightarrow \mathrm{OH}+\mathrm{OH}(+\mathrm{M})
$$

$\underline{20}$ accelerates $\mathrm{H}$ abstraction from $\mathrm{C}_{10} \mathrm{H}_{22}$ by 10 and promotes $\underline{18}$ reaction, and the temperature rapidly rises. At high temperature, the pyrolysis reaction becomes important:

$$
\mathrm{C}_{10} \mathrm{H}_{21} \rightarrow 2 \mathrm{C}_{3} \mathrm{H}_{6}+\mathrm{C}_{2} \mathrm{H}_{5}+\mathrm{C}_{2} \mathrm{H}_{4}
$$

As is known from Fig. $\underline{5}$ at $2606 \mu \mathrm{s}, \mathrm{C}_{1}-\mathrm{C}_{3}$ hydrocarbons are rapidly oxidized to $\mathrm{CO}_{2}$ by $\mathrm{O}_{2}$ and the free radicals of $\mathrm{HO}_{2}$ and $\mathrm{OH}$. With the acceleration of the oxidization reactions, the temperature sharply rises to $1828 \mathrm{~K}$ at $2606 \mu$ s (see point B in Fig. 2), and the second-stage ignition process is terminated.
B. Effects of Pressure, $\mathrm{H}_{2} \mathrm{O}_{2}$ Decomposition Rate, and $\mathrm{H}_{2} \mathrm{O}_{2}$ Concentration on Ignition Delay

In the ignition simulation of $\mathrm{H}_{2} \mathrm{O}_{2} /$ kerosene, at a given $C_{\mathrm{H} 2 \mathrm{O} 2}$, $R_{\mathrm{H} 2 \mathrm{O} 2}$ influences the initial ignition temperature and $\varphi$. The temperature of the decomposition gas mixture increases with the increase of $R_{\mathrm{H} 2 \mathrm{O} 2}, C_{\mathrm{H} 2 \mathrm{O} 2}$, and pressure [21,22]. As is known from Eq. (8), $\varphi$ decreases in the ignition stage with the increase of $R_{\mathrm{H} 2 \mathrm{O} 2}$.

Figure 6 shows the effects of pressure, $C_{\mathrm{H} 2 \mathrm{O} 2}$, and $R_{\mathrm{H} 2 \mathrm{O} 2}$ on the ignition delay time. With the increase of pressure, the ignition delay time rapidly decreases in the range from 1 to $4 \mathrm{MPa}$ (see Figs. 6a and $6 \mathrm{c}$ ) and slowly decreases at $P>4 \mathrm{MPa}$ (see Figs. $6 \mathrm{~b}$ and $6 \mathrm{~d}$ ), and this phenomenon is directly related to the oxidation of the alkyl radicals (see 11). With the increase of pressure, the equilibrium of 11 shifts toward the formation of the $\mathrm{C}_{10} \mathrm{H}_{21} \mathrm{OO}$ radical, the reaction releases a large amount of heat in the low-temperature reaction of the first-stage 


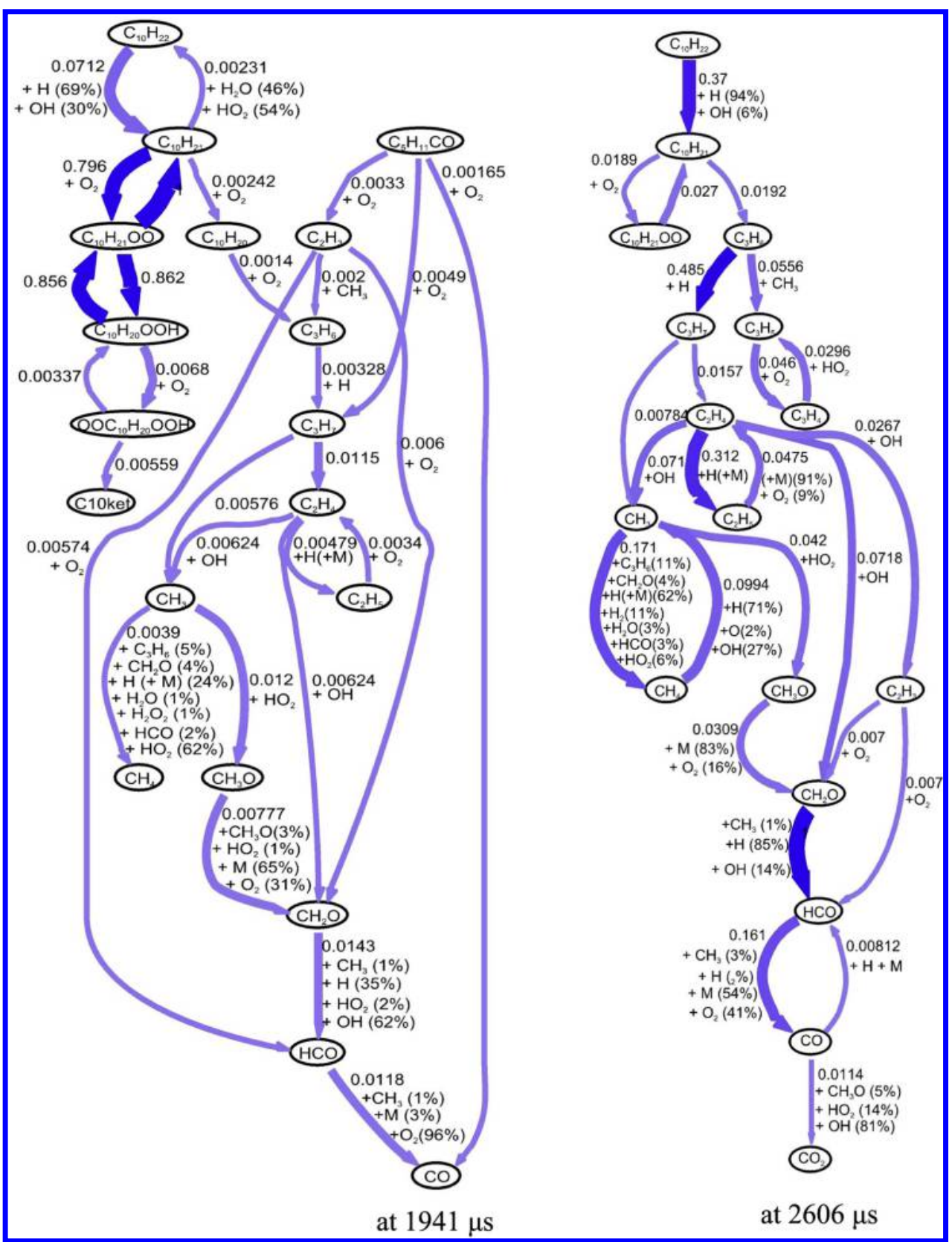

Fig. 5 Reaction path analysis of the first-stage ignition at $87 \% C_{\mathrm{H} 202}, 64 \% R_{\mathrm{H} 2 \mathrm{O} 2}$, and $1 \mathrm{MPa}$.

ignition, and this effectively reduces $\tau_{1}$ when the pressure increases from 1 to $4 \mathrm{MPa}$. Since the $\mathrm{H}_{2} \mathrm{O}_{2}$ decomposition temperature increases with pressure, the ignition time decreases with the further increase of pressure from 4 to $9 \mathrm{MPa}$, but 11 will process toward the inverse direction with the increase of temperature, and thus the variation of the ignition delay time with the increase of pressure becomes slow (see Figs. $6 \mathrm{~b}$ and $6 \mathrm{~d}$ ).

Since the low-temperature chain reactions produce a large amount of $\mathrm{H}_{2} \mathrm{O}_{2}$ by $19, \mathrm{H}_{2} \mathrm{O}_{2}$ decomposition leads to the termination of the NTC process through 21 , which is pressure-dependent reaction, and thus the $\mathrm{H}_{2} \mathrm{O}_{2}$ decomposition rate is greater at higher pressures. Therefore, increasing the pressure makes the NTC region shift to a higher $R_{\mathrm{H} 2 \mathrm{O} 2}$ range, and the corresponding NTC region becomes narrow, as shown in Fig. 7.

To investigate the influencing extent of $C_{\mathrm{H} 2 \mathrm{O} 2}$ and pressure on the NCT region, the difference of $\tau_{\min }$ and $\tau_{\max }$ is defined as

$$
\Delta \tau=\tau_{\max }-\tau_{\min }
$$

where $\tau_{\min }$ and $\tau_{\max }$ are, respectively, the minimal and maximal ignition delay times corresponding points $\mathrm{C}$ and $\mathrm{D}$ of the NCT region in Fig. 3. If the value of $\Delta \tau$ is great, the variation extent of the NCT region is noticeable. Figure $\underline{8}$ shows the influencing extent of $C_{\mathrm{H} 2 \mathrm{O} 2}$ and pressure on the NCT region corresponding to Fig. 7; the increase of pressure weakens the variation extent of the NTC. As is known from Fig. 6 , at $P>4 \mathrm{MPa}$, the NTC phenomenon of ignition nearly disappears, and the ignition process goes through only one stage governed by low-temperature chemistry [23].

In the study, when $\mathrm{H}_{2} \mathrm{O}_{2}$ is completely decomposed by catalysis $\left(R_{\mathrm{H} 2 \mathrm{O} 2}=1\right)$, the equivalence ratio is kept at 1 . If $\mathrm{H}_{2} \mathrm{O}_{2}$ is partly decomposed by catalysis, the equivalence ratio decreases with the decrease of $R_{\mathrm{H} 2 \mathrm{O} 2}$, and the decomposition temperature decreases. In Fig. $\underline{6}, R_{\mathrm{H} 2 \mathrm{O} 2}$ has complex effects on the ignition delay time: at low $R_{\mathrm{H} 2 \mathrm{O} 2}$, increasing $R_{\mathrm{H} 2 \mathrm{O} 2}$ makes $\tau_{i g}$ rapidly decrease; in the NTC region, $\tau_{i g}$ increases with $R_{\mathrm{H} 2 \mathrm{O} 2}$; and at high pressure, $\tau_{i g}$ monotonically decreases with the increase of $R_{\mathrm{H} 2 \mathrm{O} 2}$.

To further investigate the effect of $R_{\mathrm{H} 2 \mathrm{O} 2}$ on $\tau_{i g}$, the $R_{\mathrm{H} 2 \mathrm{O} 2}$ dependent coefficient of the ignition delay time is defined as

$$
\zeta=\frac{\left(\tau_{i+1}-\tau_{i}\right) / \tau_{1}}{\Delta R / R_{1}}
$$




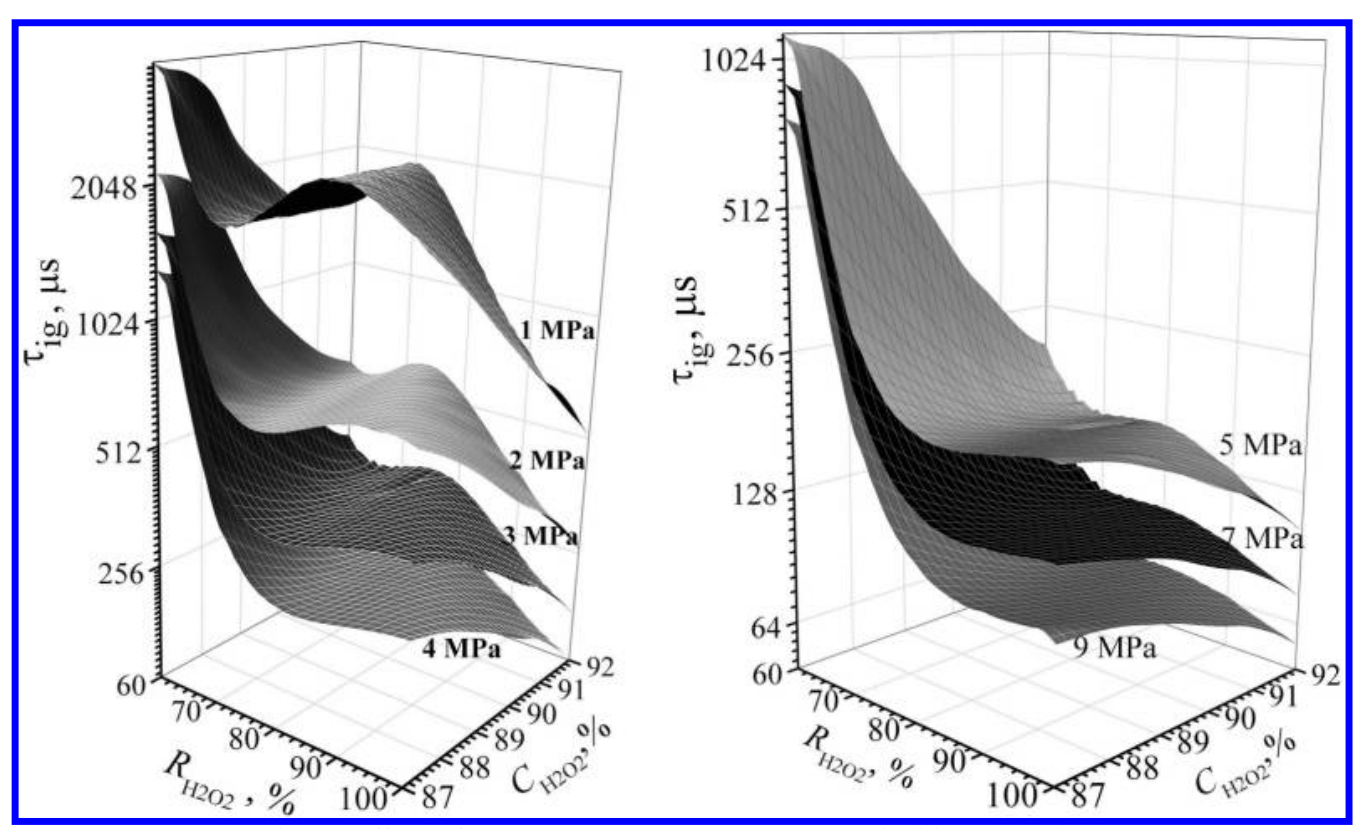

Fig. 6 Effects of pressure, $R_{\mathrm{H} 2 \mathrm{O} 2}$, and $C_{\mathrm{H} 2 \mathrm{O} 2}$ on the ignition delay time.

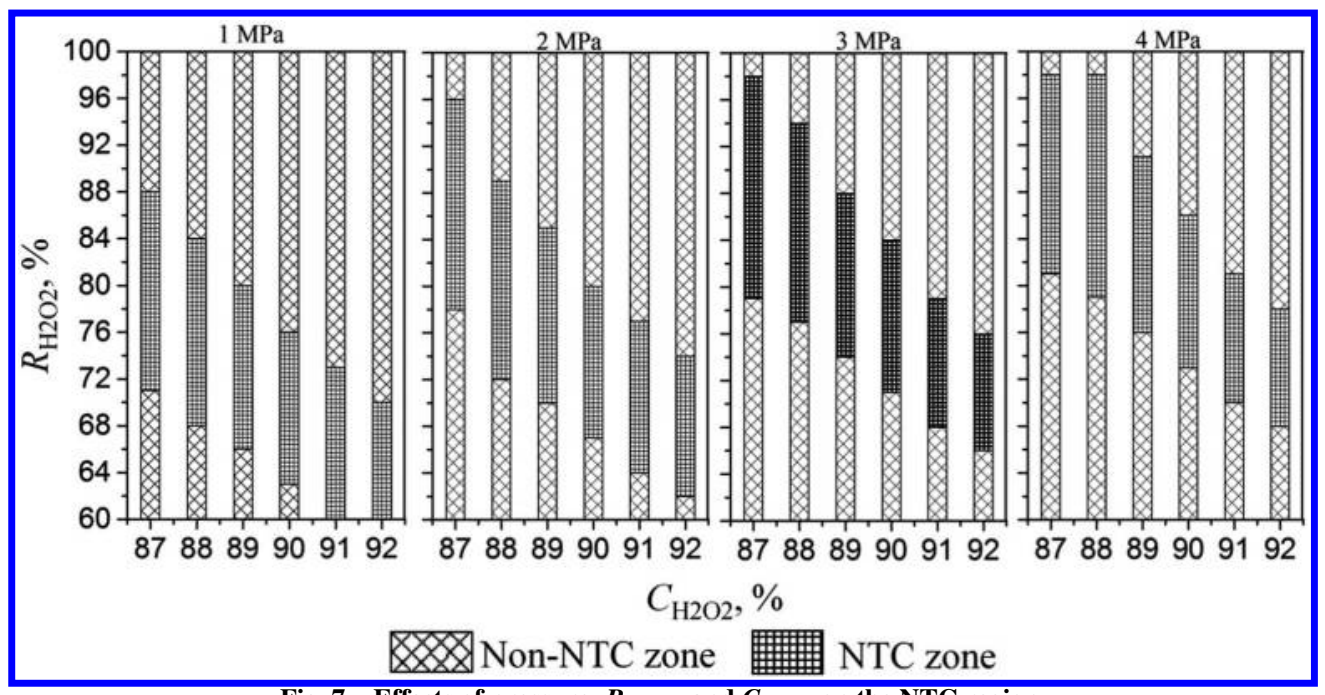

Fig. 7 Effects of pressure, $R_{\mathrm{H} 2 \mathrm{O} 2}$, and $C_{\mathrm{H} 2 \mathrm{O} 2}$ on the NTC region.

where $R_{1}$ and $\tau_{1}$, respectively, denote $60 \% \quad R_{\mathrm{H} 2 \mathrm{O} 2}$ and the corresponding ignition delay time; $\Delta R$ is the increment interval of $R_{\mathrm{H} 2 \mathrm{O} 2}$; and $\tau_{i}$ and $\tau_{i+1}$ are, respectively, the ignition delay times at $R_{\mathrm{H} 2 \mathrm{O} 2}=(60+i \Delta R)$ and $R_{\mathrm{H} 2 \mathrm{O} 2}=60+((i+1) \Delta R)$. As is known from Eq. 23 , if $\zeta$ is negative, this means that the ignition delay time decreases with the increase of $R_{\mathrm{H} 2 \mathrm{O} 2}$.

Figure 9 presents $R_{\mathrm{H} 2 \mathrm{O} 2}$-dependent coefficients of the ignition delay time at different $R_{\mathrm{H} 2 \mathrm{O} 2}$; the coefficients are almost similar when pressure is less than $4 \mathrm{MPa}$, and thus it can be considered that $\zeta$ is almost only dependent on $R_{\mathrm{H} 2 \mathrm{O} 2}$ but independent of $C_{\mathrm{H} 2 \mathrm{O} 2}$ and pressure. At $R_{\mathrm{H} 2 \mathrm{O} 2}<80 \%$, $\zeta$ rapidly varies with $R_{\mathrm{H} 2 \mathrm{O} 2}$, and it indicates $R_{\mathrm{H} 2 \mathrm{O} 2}$ has a great influence on $\tau_{i g}$. At $R_{\mathrm{H} 2 \mathrm{O} 2}>80 \%$, $\zeta$ slowly varies with $R_{\mathrm{H} 2 \mathrm{O} 2}$, and it indicates that the influence of $R_{\mathrm{H} 2 \mathrm{O} 2}$ on $\tau_{i g}$ decreases. Since the initial ignition temperature and the equivalence ratio are low at $R_{\mathrm{H} 2 \mathrm{O} 2}<80 \%$, increasing $R_{\mathrm{H} 2 \mathrm{O} 2}$ can effectively reduce the first-stage ignition delay time (see Fig. 4), the ignition delay time rapidly decreases with the increase of $R_{\mathrm{H} 2 \mathrm{O} 2}$, and the $R_{\mathrm{H} 2 \mathrm{O} 2}$-dependent coefficient of the ignition delay time rapidly increases (see Fig. 9).

In Fig. 9, the range of positive value $\zeta$ is the corresponding NTC region. Since the temperature of the $\mathrm{H}_{2} \mathrm{O}_{2}$ decomposition gas increases with $R_{\mathrm{H} 2 \mathrm{O} 2}$, the initial ignition temperature also rises with $R_{\mathrm{H} 2 \mathrm{O} 2}$ (see Fig. 1); this can effectively reduce the first-stage ignition time, but the released heat at the end of the first-ignition stage

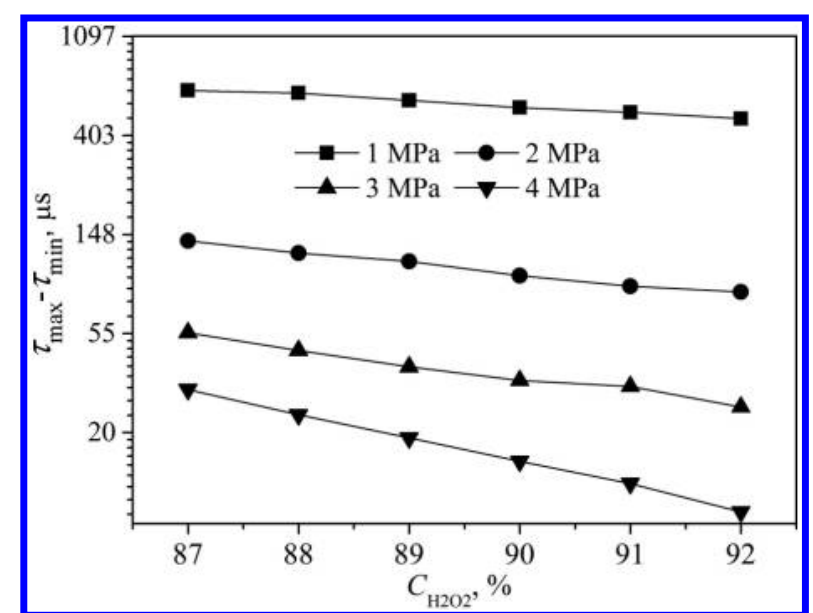

Fig. 8 Effect of $C_{\mathrm{H} 2 \mathrm{O} 2}$ and pressure on the ignition delay extent corresponding to Fig. $\underline{7}$.

decreases, which leads to a longer delay time for the second-stage ignition, and consequently the entire ignition delay time becomes longer with $R_{\mathrm{H} 2 \mathrm{O} 2}$ in the NTC region, as shown in Fig. 3 . 


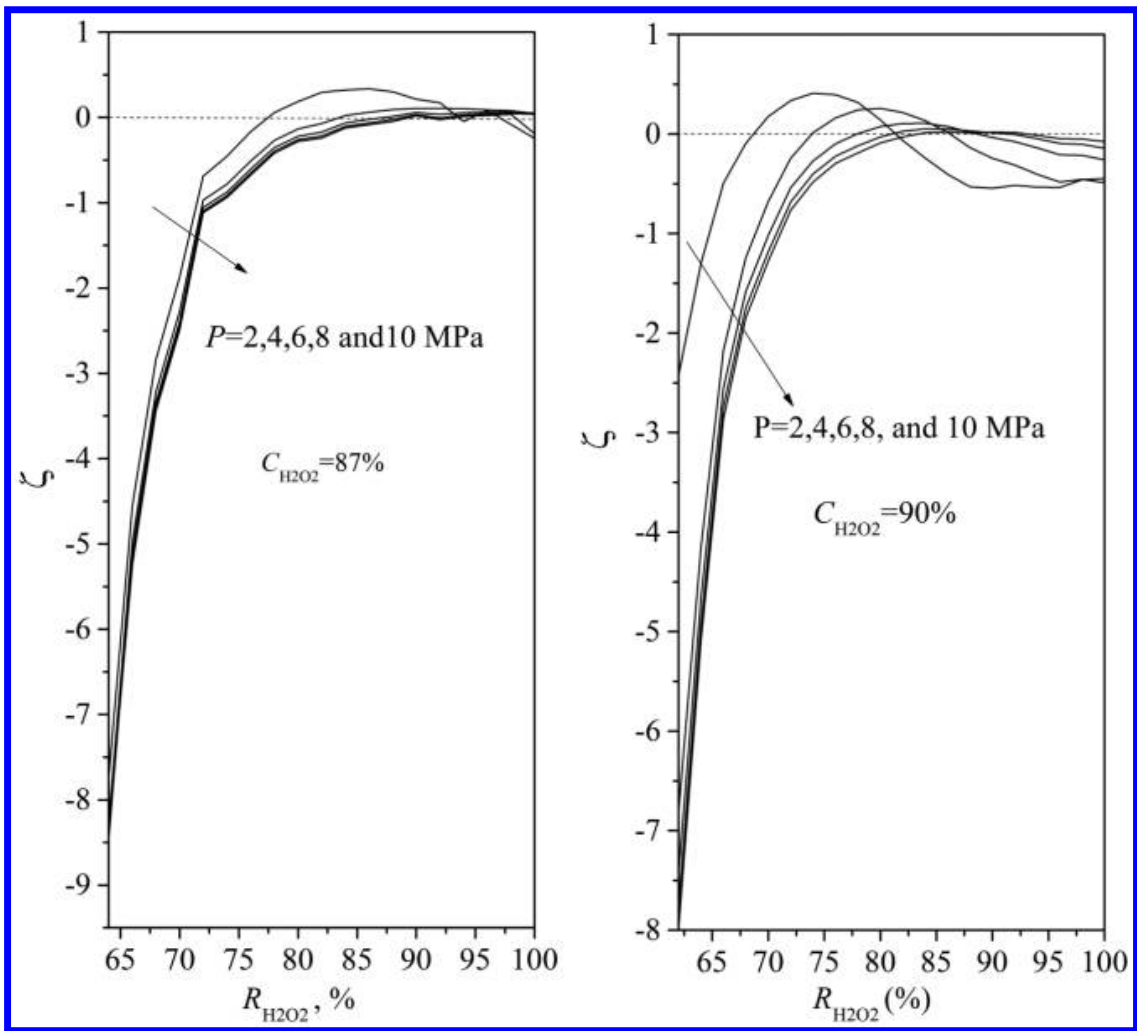

Fig. $9 R_{\mathrm{H} 2 \mathrm{O} 2}$-dependent coefficient of the ignition delay time at different $C_{\mathrm{H} 2 \mathrm{O} 2}$ and pressures.
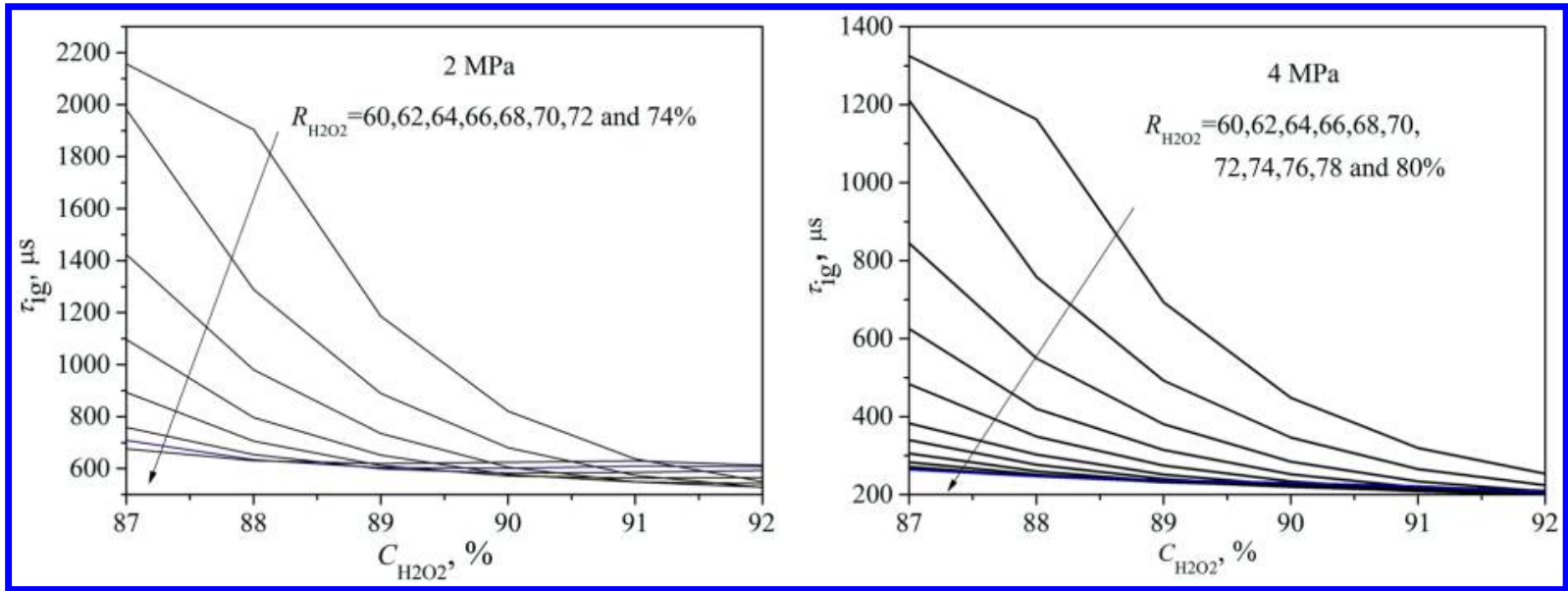

Fig. 10 Effect of $C_{\mathrm{H} 2 \mathrm{O} 2}$ on the ignition delay time.

Figure 10 shows the effect of $\mathrm{H}_{2} \mathrm{O}_{2}$ concentration on the ignition delay time, and it indicates that at $R_{\mathrm{H} 2 \mathrm{O} 2}<70 \%$ the increase of the $\mathrm{H}_{2} \mathrm{O}_{2}$ concentration can effectively reduce ignition delay time and at $R_{\mathrm{H} 2 \mathrm{O} 2}>70 \%$ the $\mathrm{H}_{2} \mathrm{O}_{2}$ concentration has a slight effect on the ignition delay time. In the study, the increasing $\mathrm{H}_{2} \mathrm{O}_{2}$ concentration means the increase of the initial ignition temperature and $\mathrm{O}_{2}$ concentration in the $\mathrm{H}_{2} \mathrm{O}_{2}$ decomposition mixture gas, and thus the ignition delay rapidly decreases with the $C_{\mathrm{H} 2 \mathrm{O} 2}$ at $R_{\mathrm{H} 2 \mathrm{O} 2}<70 \%$.

\section{Conclusions}

In this study, fuel $n$-decane is used as a surrogate fuel for kerosene; the effects of $C_{\mathrm{H} 2 \mathrm{O} 2}, R_{\mathrm{H} 2 \mathrm{O} 2}$, and pressure on the ignition chemical delay are investigated; and the reaction paths of the ignition process are provided.

The ignition delay time has the negative temperature coefficient (NTC) phenomenon for a low $\mathrm{H}_{2} \mathrm{O}_{2}$ decomposition rate, $\tau_{i g}$ increases with $R_{\mathrm{H} 2 \mathrm{O} 2}$ in the NCT region, the increasing pressure makes the NTC region shift to a higher $R_{\mathrm{H} 2 \mathrm{O} 2}$ range and weakens the variation extent of the NTC, the corresponding NTC region becomes narrow, and the NTC phenomenon of ignition delay nearly disappears when pressure is greater than $4 \mathrm{MPa}$. The $R_{\mathrm{H} 2 \mathrm{O} 2}$-dependent coefficient of the ignition delay time is almost independent of $C_{\mathrm{H} 2 \mathrm{O} 2}$ and the pressure when the pressure is less than $4 \mathrm{MPa}$, and $R_{\mathrm{H} 2 \mathrm{O} 2}$ has a great influence on $\tau_{i g}$ at $R_{\mathrm{H} 2 \mathrm{O} 2}<80 \%$. Increasing the $\mathrm{H}_{2} \mathrm{O}_{2}$ concentration can effectively reduce the ignition delay time at $R_{\mathrm{H} 2 \mathrm{O} 2}<70 \%$, and the $\mathrm{H}_{2} \mathrm{O}_{2}$ concentration has a slight effect on the ignition delay time at $R_{\mathrm{H} 2 \mathrm{O} 2}>70 \%$.

\section{Acknowledgments}

Financial support by National Natural Science Foundation of China (grant number 51376189) is acknowledged.

\section{References}

[1] Cervone, A., Torre, L., d'Agostino, L., Musker, A. J., Roberts, G. T., Bramanti, C., and Saccoccia, G., "Development of Hydrogen Peroxide Monopropellant Rockets," AIAA Paper 2006-5239, 2006. 
[2] Zhang, T., Cong, Y., and Li, T., "Propulsive Performance of Hypergolic $\mathrm{H}_{2} \mathrm{O}_{2}$ /Kerosene Bipropellant," Journal of Propulsion and Power, Vol. 31, No. 6, 2004, pp. 83-86. doi: $10.2514 / 1.9189$

[3] Krishnan, S., Ahn, S. H., and Lee, C. W., "Design and Development of a Hydrogen-Peroxide Rocket-Engine Facility," Journal Mekanikal, Vol. 30, No. 6, 2010, pp. 24-36.

[4] Musker, A. J., Rusek, J. J., and Kappenstein, C., "Hydrogen Peroxide: From Bridesmaid to Bride," 3rd ESA International Conference on Green Propellants for Space Propulsion, ESA Paper E11690/635, Sept. 2006.

[5] Moon, Y. J., Park, C., Jo, S., and Kwon, S., "Design Specifications of $\mathrm{H}_{2} \mathrm{O}_{2}$ /Kerosene Bipropellant Rocket System for Space Missions," Aerospace Science and Technology, Vol. 33, No. 6, 2014, pp. 118-121. doi:10.1016/j.ast.2014.01.006

[6] Heister, S. D., Anderson, W. E., and Corpening, J. H., "A Model for Thermal Decomposition of Hydrogen Peroxide," 40th AIAA Joint Propulsion Conference and Exhibit, AIAA Paper 2004-3373, 2004.

[7] Palmer, M. J., Musker, A. J., and Roberts, G. T., "Experimental Assessment of Heterogeneous Catalysts for the Decomposition of Hydrogen Peroxide," 47th AIAA Joint Propulsion Conference and Exhibit, AIAA Paper 2011-5695, Aug. 2011.

[8] Sébastien, M. C., "Combustion Instabilities Coupled by Pressure Waves and Their Active Control," Symposium (International) on Combustion, Vol. 24, No. 6, 1992, pp. 1277-1296. doi:10.1016/S0082-0784(06)80150-5

[9] Timothe'e, L. P., and William, E. A., "Hypergolic Reaction Mechanisms of Catalytically Promoted Fuels with Rocket Grade Hydrogen Peroxide," Combustion Science and Technology, Vol. 179, No. 10, 2007, pp. 2107-2133. doi: $10.1080 / 00102200701386149$

[10] Saksena, P., Tadigadapa, S., and Yetter, R. A., "Study of Hypergolic Propellants Using Micro-Reactors," 15th International Conference on Miniaturized Systems for Chemistry and Life Sciences, Curran Associates, Inc., New York, Oct. 2011, pp. 1594-1596.

[11] Galfetti, L., Nasut, F., Pastrone, D., and Russo, A. M., "An Italian Network to Improve Hybrid Rocket Performance: Strategy and Results," Acta Astronautica, Vol. 96, Nos. 3-4, March-April 2014, pp. 246-260. doi:10.1016/j.actaastro.2013.11.036

[12] Shahabuddin, M., Liaquat, A. M., Masjuki, H. H., Kalam, M. A., and Mofijur, M., "Ignition Delay, Combustion and Emission Characteristics of Diesel Engine Fueled with Biodiesel," Renewable and Sustainable Energy Reviews, Vol. 21, No. 5, May 2013, pp. 623-632. doi:10.1016/j.rser.2013.01.019
[13] Culick, F. E. C., "Unsteady Motions in Combustion Chambers for Propulsion Systems," California Inst. of Technology, Rept. AC/323 (AVT-039), Pasadena, CA, 2006.

[14] Zeng, W., Liu, J. C., Chen, X. X., and Ma, H. A., “A New Reduced Reaction Mechanism of a Surrogate Fuel for Kerosene," Canadian Journal of Chemical Engineering, Vol. 91, No. 3, 2013, pp. 483-489. doi:10.1002/cjce. 21674

[15] Zeng, W., Liang, S., Li, H. X., and Ma, H. A., "Chemical Kinetic Simulation of Kerosene Combustion in an Individual Flame Tube," Journal of Advanced Research, Vol. 5, No. 3, 2014, pp. 357-366. doi:10.1016/i.jare.2013.06.002

[16] Dagaut, P., and Cathonnet, M., "The Ignition, Oxidation, and Combustion of Kerosene: A Review of Experimental and Kinetic Modeling," Progress in Energy and Combustion Science, Vol. 32, No. 6, 2006, pp. $48-92$. doi:10.1016/j.pecs.2005.10.003

[17] Chang, Y. C., Jia, M., and Liu, Y. D., "Development of a New Skeletal Mechanism for n-Decane Oxidation Under Engine-Relevant Conditions Based on a Decoupling Methodology," Combustion and Flame, Vol. 160, No. 8, 2013, pp. 1315-1332. doi:10.1016/j.combustflame.2013.02.017

[18] Goodwin, D. G., "Object-Oriented Software for Reacting Flows Network," California Inst. of Technology, Pasadena, CA, 2011, http:// www.cantera.org/docs /sphinx/html/index.html.

[19] Kee, R. J., Rupley, F. M., and Meeks, E., "A FORTRAN Chemical Kinetics Package for the Analysis of Gas Phase Chemical Kinetics," Sandia National Lab., UC-40 SAND96-8126, Livermore, CA, 1996.

[20] Lutz, A. E., Kee, R. J., and Miller, J. A., "SENKIN: A FORTRAN Program for Predicting Homogeneous Gas Phase Chemical Kinetics with Sensitivity Analysis," Sandia National Lab., SAND87-8248, Livermore, CA, 1997.

[21] Walsh, R. F., and Sutton, A. M., "Pressure Effects on Hydrogen Peroxide Decomposition Temperature," 5th International Hydrogen Peroxide Propulsion Conference, Purdue Univ., Lafayette, IN, Sept. 2002, pp. 1-13.

[22] Ge, M. L., Li, Q., and Liu, Y. K., "A Calculation Method of Decomposing Hydrogen Peroxide from Silver Catalyst Bed," Journal of Rocket Propulsion, Vol. 35, No. 5, 2009, pp. 39-45 (in Chinese).

[23] Law, C. K., and Zhao, P., "NTC-Affected Ignition in Nonpremixed Counterflow," Combustion and Flame, Vol. 159, No. 3, 2012, pp. 1044-1054. doi:10.1016/j.combustflame.2011.10.012

L. Maurice Associate Editor 